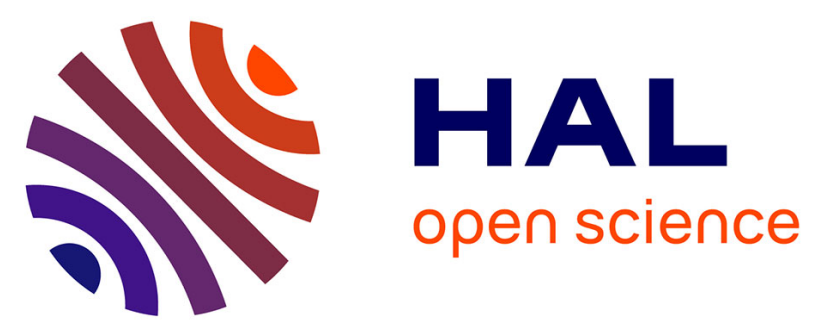

\title{
Cut-over peatland regeneration assessment using organic matter and microbial indicators (bacteria and testate amoebae).
}

Fatima Laggoun-Défarge, Edward P. Mitchell, Daniel Gilbert, Jean-Robert

Disnar, Laure Comont, Barry Warner, Alexandre Buttler

\section{To cite this version:}

Fatima Laggoun-Défarge, Edward P. Mitchell, Daniel Gilbert, Jean-Robert Disnar, Laure Comont, et al. Cut-over peatland regeneration assessment using organic matter and microbial indicators (bacteria and testate amoebae).. Journal of Applied Ecology, 2008, 45 (2), pp.716-727. 10.1111/j.13652664.2007.01436.x . hal-00142062

\section{HAL Id: hal-00142062 \\ https://hal-insu.archives-ouvertes.fr/hal-00142062}

Submitted on 17 Apr 2008

HAL is a multi-disciplinary open access archive for the deposit and dissemination of scientific research documents, whether they are published or not. The documents may come from teaching and research institutions in France or abroad, or from public or private research centers.
L'archive ouverte pluridisciplinaire HAL, est destinée au dépôt et à la diffusion de documents scientifiques de niveau recherche, publiés ou non, émanant des établissements d'enseignement et de recherche français ou étrangers, des laboratoires publics ou privés. 
Assessing cutover peatland regeneration by combined analyses of organic matter properties, bacteria, and testate amoebae (Protista)

Laggoun-Défarge Fatima ${ }^{1 *}$, Mitchell Edward ${ }^{2}$, Gilbert Daniel ${ }^{3}$, Disnar JeanRobert ${ }^{1}$, Comont Laure ${ }^{1}$, Warner Barry G. ${ }^{4}$, Buttler Alexandre ${ }^{5,6,7}$

${ }^{1}$ ISTO, UMR 6113 CNRS - Université d'Orléans, BP 6759, 45067 Orléans cedex 2, France

2 WSL, Swiss Federal Research Institute, Ecosystem Boundaries Research Unit, Wetlands Research Group, Station 2, CH - 1015 Lausanne, Switzerland

${ }^{3}$ Laboratoire de Biologie Environnementale, EA 3184 (USC INRA - Université de Franche Comté), 25030 Besançon cedex, France

${ }^{4}$ Wetlands Research Center, University of Waterloo, Ontario, N2L 3G1, Canada

${ }^{5}$ École Polytechnique Fédérale de Lausanne (EPFL), Laboratory of Ecological Systems (ECOS), Station 2, CH - 1015 Lausanne, Switzerland

${ }^{6}$ WSL, Swiss Federal Research Institute, Community Ecology Research Unit, Restoration Ecology Research Group, Station 2, CH - 1015 Lausanne, Switzerland

${ }^{6}$ Laboratoire de Chrono-Ecologie, UMR 6565 CNRS - Université de Franche-Comté, 25030 Besançon cedex, France

\section{Corresponding authors:}

Fatima.Laggoun-Defarge@univ-orleans.fr \& edward.mitchell@epfl.ch

Fax: F. L.-D.: +33 2384173 08; E. M.: +41 216933913

Word count of the paper: 8188

Keywords: carbohydrates, $\mathrm{C} / \mathrm{N}$, micromorphology, microorganisms, peat composition, RECIPE, restoration ecology, secondary succession, Sphagnum, source and degradation biomarkers

Running title: Organic matter and microorganisms in a cutover bog 


\section{Abstract}

1. Cutover peatlands are valuable as habitat for rare species and as carbon sinks. However, assessing peat accumulation is complicated. Approaches such as using biological and physico-chemical indicators may represent an alternative for managers.

2. In order to assess the potential of biological and physico-chemical parameters as restoration indicators, we studied the organic matter $(\mathrm{OM})$, testate amoebae and bacteria in peat profiles from a cutover bog. We selected four regeneration stages and an unexploited area of the same peatland. Living Sphagnum was analysed for testate amoebae. Physico-chemical parameters were analysed on near-surface peat profiles.

3. Contrasting micromorphological and biochemical signatures of peat OM were observed along the profiles. Regenerating and natural peat profiles differ with respect to $\mathrm{C} / \mathrm{N}$ ratio and $\mathrm{OM}$ degradation.

4. The OM composition of the newly regenerated peat also differed along the regeneration sequence. Peats from the recent regenerated sites were dominated by Sphagnum-derived tissues and were characterised by lesser carbohydrate preservation and a high bacterial biomass in comparison to the peat from older regenerating sites which showed a heterogeneous botanical composition and lower bacterial biomass.

5. Moss OM inputs are characterised by hemicellulosic mannose and galactose, while sedge inputs are characterised by hemicellulosic xylose and arabinose. Additional indicators of OM alteration included the differential biodegradation of cellulose and hemicellulose. 
6. Testate amoeba communities changed from the early to the advanced stages of regeneration suggesting a shift from wet and mesotrophic conditions to drier and more acidic conditions. Species richness and diversity increased but density declined from the early to the late regeneration stage and the unexploited site. Biomass and the average size of species declined over the regeneration sequence but were higher in the unexploited site.

7. The spontaneous secondary succession in the studied cutover bog leads to an ecosystem similar to that of the intact reference site in terms of community structure while $\mathrm{OM}$ characteristics and testate amoebae continue to reflect disturbances associated with peat harvesting. This combination of biological and physico-chemical indicators provides a complete assessment of the present and recent past ecological conditions. Such an approach has practical applications for the management of cutover peatlands. 


\section{INTRODUCTION}

Regenerating peatlands may act as carbon sinks, and can be important for rare and endangered species (Chapman et al. 2003). Therefore much effort is now directed to encourage the re-establishment of peat-forming vegetation and especially Sphagnum mosses (Grosvernier, Matthey \& Buttler, 1995; Gorham \& Rochefort 2003; Lavoie et al. 2003). However, the outcome of these restoration efforts with respect to carbon balance remains difficult to predict and, in many cases, local conditions may not allow net accumulation of carbon to occur (Francez, Gogo \& Josselin 2000; McNeil \& Waddington 2003).

Most of the work on carbon dynamics in peatlands has been approached by measurements of processes occurring either on the surface or in the peat, in most cases by estimating surface fluxes of $\mathrm{CO}_{2}$ and $\mathrm{CH}_{4}$ (Harriss et al. 1985; Knowles \& Moore 1989; Moore \& Knowles 1989; McNeil \& Waddington 2003). There has been relatively little attempt to examine key processes occurring at depth. Little is known about the quality of the organic matter $(\mathrm{OM})$ and the characteristics of the microbial communities responsible for its biochemical transformation, in natural peatlands in general, and especially in cutover sites. Studies suggest that these aspects have important implications for the functioning of the ecosystem. Indeed, the physiochemical and botanical properties of the underlying peat were shown to strongly affect (i) the growth of Sphagnum mosses (Grosvernier, Matthey \& Buttler 1997; Buttler, Grosvernier \& Matthey 1998), and (ii) gas fluxes to the atmosphere (Buttler, Dinel \& Lévesque 1994; Charman, Aravena \& Warner 1994), while microbial communities were shown to respond to ecological gradients as well as ecosystem 
perturbations such as $\mathrm{N}$ input or elevated atmospheric $\mathrm{CO}_{2}$ concentrations (Gilbert et al. 1998a,b; Mitchell et al. 2003).

Clearly, in order to refine management strategies for cutover peatlands, more information is needed on (1) the patterns of changes in the community structure of different taxonomic groups and in the physico-chemical characteristics of the peat $\mathrm{OM}$ and (2) the processes controlling long-term carbon sequestration during peatland regeneration. These are two of the main goals of the EU-funded project RECIPE (Reconciling commercial exploitation of peat with biodiversity in peatland ecosystems) (Chapman et al. 2003). Our focus here is on testate amoebae (Protista), bacteria, and biochemical characteristics of peat OM. These indicators are generally not considered together in peatland restoration studies, but they may react faster than other indicators to the changes occurring during peatland regeneration and are likely to provide valuable information on processes occurring in the soil (Warner \& Chmielewski 1992; Chapman et al. 2003).

We studied abiotic and biotic aspects of peat in a suite of secondary plant communities situated on a cutover peatland in the Swiss Jura Mountains: 1) the depthrelated changes of biochemical and micromorphological characteristics of peat OM, 2) the bacteria $\mathrm{C}$ biomass at different depths, and 3) the abundance, diversity, and community structure of testate amoebae living in the Sphagnum mosses at the surface. Our aims were to assess how these different variables were correlated and to identify specific indicators of changes in the structure or the functioning of the ecosystem. Because of the clear changes that can be observed directly from the structure of the vegetation along the regeneration sequence, we hypothesised that both the accumulated $\mathrm{OM}$ and the related microbial indicators would also differ, but we could 
not predict how the different data sets might compare and to which extent they would reflect ecosystem recovery.

\section{MATERIAL AND METHODS}

\section{Study site and sampling}

La Chaux d'Abel, a cutover peatland in the Jura Mountains, Switzerland (47.09 ${ }^{\circ} \mathrm{N}$, $6.56^{\circ} \mathrm{E}$; altitude $1,020 \mathrm{~m}$ a.s.1.), was sampled in November 2001. The mean annual precipitation and temperature is $1463 \mathrm{~mm}$ and $6.4^{\circ} \mathrm{C}$ respectively. The site was abandoned after active peat cutting ceased in 1963 with only a small area remaining intact. Subsequently, spontaneous regeneration took place and, at present, mosse and vasculat plant communities have developed for variable lengths of time on different parts of the site (Matthey 1996). Five sites were selected as representative of natural and secondary plant communities in cutover peatland of the region: a wet fen community representing an early regeneration stage (sites $1 \& 2$ ), a transitional zone between the fen and the bog (site 3), an advanced regeneration stage (with scattered trees) in the bog (site 4), and as a reference, an unexploited area in the same peat bog (hereafter coded "unexploited") (Table 1).

Three replicate peat cores, $13 \mathrm{~cm}$ in diameter were extracted in each community adding up to a total of 15 cores. The 60 to $70 \mathrm{~cm}$ long cores were cut into $2 \mathrm{~cm}$ thick slices. One part of each subsample was used for chemical analyses after air drying and pulverising into a powder and kept at $4^{\circ}$, and the other part destined to micromorphology and bacteria analyses was fixed in a $2 \%$ glutaraldehyde solution and kept at $4^{\circ} \mathrm{C}$. The uppermost $3 \mathrm{~cm}$ of living plants were analysed for testate 
amoebae, whereas $\mathrm{OM}$ and bacteria analyses were conducted on the whole profile (10-13 samples per profile).

\section{Laboratory and data analyses}

\section{Testate amoebae}

Testate amoebae were extracted from the samples by sieving on $20 \mu \mathrm{m}$ and $300 \mu \mathrm{m}$ mesh (Hendon \& Charman 1997). All shells, live, encysted, and dead shells were identified and counted under microscope at 200X and 400X magnifications. Biovolumes of each living (active and encysted) species were estimated by assuming geometrical shapes and converted to carbon using the conversion factor: $1 \mu \mathrm{m}^{3}=0.11$ $510^{-6} \mu \mathrm{gC}$ (Weisse et al. 1990). Nomenclature for testate amoebae follows the latest edition of the illustrated guide to the protozoa (Meisterfeld 2000a,b).

We compared the sampling sites for a set of five general variables derived from the testate amoebae data: total density (living + dead), percentage of living species, carbon biomass, species richness, and the Shannon-Wiener diversity index $\left(H^{\prime}\right.$, using the base 2 logarithm). The average values were compared using an ANOVA followed by comparison of all pairs (Turkey-Kramer HSD). To assess how communities change during the regeneration sequence, we inferred the water table depth (WTD) and $\mathrm{pH}$ using a transfer function based on a data set from an earlier study in the same region (Mitchell et al. 1999; Mitchell et al. 2001). The calculations were performed using the software WA-CALIB (Line, ter Braak \& Birks 1994). The resulting values were used to draw a plot of inferred DWT vs $\mathrm{pH}$ for the samples. 


\section{Bacterial density}

Bacteria were stained with DAPI (4,6 diamino 2 phenylindol), filtered on $0.2 \mu \mathrm{m}$ black membrane filters and examined by epifluorescence microscopy at 1000X magnification for all peat levels. The image was recorded using a digital camera. Bacteria numbers and sizes were estimated on a minimum of 10 random fields for each sample. Bacterial biovolumes were estimated by assuming geometrical shapes and converted to carbon using the following conversion factor: $1 \mu \mathrm{m}^{3}=5.6 \times 10^{-7} \mu \mathrm{gC}$ (Bratbak 1985).

Organic matter: $C, N$, Micromorphological and sugar analyses

Total carbon and nitrogen were determined by combustion at $1100^{\circ} \mathrm{C}$ with a $\mathrm{CNS}$ LECO 2000 apparatus on dried and crushed samples. Because of the absence of inorganic carbon (carbonates) the determined total $\mathrm{C}$ represents Total Organic Carbon and was used for $\mathrm{C} / \mathrm{N}$ calculation.

Identification and quantification of peat constituents were carried out under transmitted light microscope. Bulk peat samples were mounted as smear slides and examined at 20 and 50X magnification. The surfaces covered by the main organic micro-remains were estimated with a grid reticule in the eyepiece of the microscope. A total of 3000 to 5000 items per sample were counted to calculate relative frequencies with an estimated error of about 10\% (Noël 2001).

A detailled procedure for sugar analysis is given in Comont, Laggoun-Défarge \& Disnar (2006). Briefly, two aliquots (ca. $100 \mathrm{mg}$ ) of a given sample are hydrolysed (4 hrs at $100^{\circ} \mathrm{C}$ ) in $1.2 \mathrm{M} \mathrm{H}_{2} \mathrm{SO}_{4}$ solution, one after previous soaking with $24 \mathrm{~N} \mathrm{H}_{2}$ $\mathrm{SO}_{4}$ (12 hrs at room temperature) but not the other. After hydrolysis and adequate sample treatment, individual sugars are silylated and quantified by gas 
chromatography using an internal standard, the individual compound response coefficients being determined independently with a mixture of eight common monosaccharides. The two hydrolyses release the total and the hemicellulosic sugars, respectively. The cellulosic sugars are determined by difference. Replicate analyses gave an analytical precision of $10 \%$ to $15 \%$. Sugar analyses were first conducted on the characteristic peat-forming plants sampled from Le Russey peatlands, in the French Jura, about $15 \mathrm{~km}$ away from the study site (Comont, Laggoun-Défarge \& Disnar 2006). The variation in the composition of hemicellulose from one species to another provided plant-source signatures: xylose and arabinose for E. vaginatum and E. angustifolium; mannose for P. strictum, and rhamnose and galactose for S. fallax. These specific signatures were then used in this study to reconstruct past vegetation changes in the underlying peat.

\section{RESULTS}

\section{Testate amoebae}

A total of 22 testate amoebae taxa were encountered in this study (Table 2). The overall average and detail for each site for species richness, H' diversity, percentage of living and encysted individuals, density and $\mathrm{C}$ biomass are given in Table 3 .

Significant differences in species richness were found among the five sites. The highest species richness was found in sites 3 and the unexploited site, while site 4 had an intermediate diversity and the two early succession sites (1 and 2) had low species richness (Table 3). The pattern of diversity as measured using the Shannon-Wiener $H^{\prime}$ index is similar to that of species richness: H' diversity were lower at sites 1 and 2 of 
the regenerating sites compared to values from sites 3 and 4 and the unexploited site (Table 3).

The percentage of living and encysted testate amoebae was higher in sites 1 and $2(63-64 \%)$ than in the other three sites $(49-52 \%)$, but this difference was not significant. The highest overall testate amoeba densities were observed in sites 1 and 2, and to a lesser extent site 3 . The $\mathrm{C}$ biomass was significantly higher in sites 1 and 2 than in the other three sites. The lowest $\mathrm{C}$ biomass was recorded in site 4 , which was significantly lower than that of the unexploited site (Table 3). The differences between the density and $\mathrm{C}$ biomass results are due to the change in community structure between sites 1 and 2 vs. sites 3 and 4: smaller species such as Assulina muscorum and Nebela tincta increased at the expense of the larger Hyalosphenia papilio. The significantly higher biomass recorded in the unexploited site is due to the presence of large species (e.g. Bullinularia indica, Arcella catinus) and the dominance of medium-sized taxa (Nebela tincta, N. tincta var. major, Assulina seminulum and Helopera sylvatica).

Clear differences in testate amoebae communities were found along the regeneration sequence (Fig. 1). The early stages are dominated by Hyalosphenia papilio, a species indicative for wet conditions in the Jura peatlands (Mitchell et al. 1999). In the intermediate stage, Archerella flavum (synonym: Amphitrema flavum) an indicator of wet, acidic and oligotrophic conditions in the region (Mitchell et al. 1999), reaches its highest relative abundance and two indicators of drier and more acidic conditions, Nebela tincta, and Assulina muscorum increase in abundance. Advanced stages are dominated by Nebela tincta, Assulina muscorum and another dry and acidic indicator Corythion dubium (Mitchell et al. 1999). In the water table depth $\mathrm{x} \mathrm{pH}$ biplot where the values for each samples were calculated based on the testate 
amoeba community data using a transfer-function the samples are aligned from the initial to intermediate and advanced succession stages suggesting a continuous trend towards drier and more acidic conditions (Fig. 1). Illustrations of the key testate amoeba indicator species are given in Fig. 4.

\section{Bacteria}

Overall, bacterial density and biomass averaged $4.84 \times 10^{10}$ cells and $1.24 \mathrm{mgC.} \mathrm{g}^{-1} \mathrm{dw}$ of peat respectively, and were not significantly different among the five sites. Bacterial biomass tended to decline from the young to the advanced regeneration stages, but this trend was not significant (Fig. 2). Biomass decreased with depth in the top $40 \mathrm{~cm}$ in the early regeneration stages (respectively $1.91,1.44$ and 1.91 in the upper $25 \mathrm{~cm}$ and $0.81,1.13$ and $0.61 \mathrm{mgC}^{-1} \mathrm{dw}$ in the peat below $25 \mathrm{~cm}$ depth in sites 1-3), while it was stable with a rise at the lower level for the late regeneration stage (site 4) and the unexploited zone. As a consequence of these vertical patterns, bacterial biomass was significantly higher in the upper peat (top $25 \mathrm{~cm}$ ) of sites 1-3 than in the upper peat of site 4 (ANOVA with Fisher's protected least square differences, respectively $P=0.0009, P=0.029$ and $P=0.002$ ), and in the upper peat of sites 1 and 3 as compared to the upper peat of the unexploited site (resp. $P=0.018$ and $P=0.025)$. In the lower sections of the cores by contrast the difference were no longer correlated to the regeneration sequence. However, bacterial biomass was positively correlated to the $\mathrm{C} / \mathrm{N}$ ratio and the relative percentage of Sphagnum remains in the peat (Fig. 3). 


\section{Peat organic matter}

\section{Carbon and nitrogen contents}

Overall, total organic carbon contents are high (ranging between 40 and 51\%). In the unexploited zone, the profiles of $\mathrm{C} / \mathrm{N}$ ratios vary little with depth (60 to 80), except at 20-25 $\mathrm{cm}$ and 48-62 $\mathrm{cm}$ depth where they significantly decrease (30 to 40) revealing thus either a higher OM degradation and/or changes in the OM sources (Fig. 3). By contrast, in the two formerly exploited zones (sites 1 and 4), they show a contrasted pattern between two sections: the upper one ( 0 to $\approx 25 \mathrm{~cm}$ depth) corresponding to the "new" regenerated peat and below, the "old" catotelm peat (Fig. 3). The latter horizon is characterised by rather low $\mathrm{C} / \mathrm{N}$ ratios (20 to 30 , especially in site 1 ) unlike the regenerated peat where the ratios are much higher (60 to 100).

\section{Micromorphological characteristics}

Characteristic tissues deriving from vascular plants, particularly from Cyperaceae (Fig. 4g) and mosses (Fig. 4h-j) have been identified and counted in the peat samples. Most of the Sphagna- and Polytrichum-derived tissues found in the peat consist of characteristic leaf cell walls (Fig. 4i-j-h). Two classes of tissues (well-preserved and degraded) depending on their alteration biostructure degree (Fig. 4g-j; 4k-o). Amorphous OM flakes (Fig. 41-o) present in various proportions consist of a complete amorphisation of the cell walls. Another "amorphous" component, namely the mucilage (Fig. 4k,n\&o) is also present as slimy and translucent substances with no internal structure. This component is more likely derived, at least partly, from in situ microbial syntheses of bacteria, fungi and/or plant roots (Decho 1990; Défarge et al. 1996; Laggoun-Défarge et al. 1999). Many tangled masses of melanised fungal hyphae (Fig. 4o) often associated with decayed plant rootlets are also present in the 
so-called "old" peat. The microorganisms (Fig. 4a-f\&j) are mostly represented by algae, testate amoebae, and more rarely, diatoms, shells of the bdelloid rotifer Habrotrocha angusticollis often found in peat.

As for the $\mathrm{C} / \mathrm{N}$ ratios, the depth evolution of the relative abundance of the organic micro-remains shows contrasting signatures between the profiles (Fig. 3): in the unexploited zone peat $\mathrm{OM}$ is exclusively composed of morphologically wellpreserved, and to a lesser extent degraded tissues mainly derived from Sphagnum mosses, except in the two levels $(20-25 \mathrm{~cm}$ and $48-62 \mathrm{~cm}$ depth) where the $\mathrm{C} / \mathrm{N}$ ratios significantly decrease which are characterised by (i) a higher degradation as revealed by the abundance of structure-less plant tissues, amorphous OM and mucilage and (ii) the occurrence of well-preserved Cyperaceae tissues. The OM composition in these two levels may highlight events such as natural and/or anthropogenic drainage phases, which would have allowed the establishment of specific vascular plants such as sedges. Peat OM composition of the profiles from the formerly exploited sites ( 1 and 4, Fig. 3) confirms also the $\mathrm{C} / \mathrm{N}$ results. Two sections are distinguished, a deeper "old" peat characterised by strong OM degradation as shown by high amounts of amorphous OM, structure-less plant tissues and mucilage, and an upper "new" regenerated peat composed mainly of well-preserved plant tissues. According to the regeneration stage, the "new" peat shows different OM compositions: in site 1 being exclusively composed of Sphagnum mosses, while its composition is more heterogeneous in the later regeneration stage (site 4) (Fig. 3a \& b).

\section{Sugar contents and distributions}

The results of sugar analyses from characteristic peat-forming plants previously reported (Comont, Laggoun-Défarge \& Disnar 2006) are summarised in Table 4. The 
quantitative and qualitative evolution of peat carbohydrates in the peat profiles of the two regeneration stages (sites 1 and 4) and the unexploited zone are presented in Fig. 5.

In site 1 (and to a lesser extent in site 4), the depth-related changes in total sugar yields allows two peat sections to be distinguished along the profiles: the uppermost peat ( 0 - 20/25 cm depth) contains high sugar contents $\left(250\right.$ to $\left.400 \mathrm{mg} \cdot \mathrm{g}^{-1}\right)$ which are in the same range as those found in the living plants: $282,326,400$ and $357 \mathrm{mg} . g-^{1}$ for E. angustifolium, E. vaginatum, P. strictum and S. fallax respectively (Comont, Laggoun-Défarge \& Disnar 2006). By contrast, in the underlying peat sugar yields strongly decrease down to ca. $70 \mathrm{mg} \cdot \mathrm{g}^{-1}$ in site 1 and ca. $160 \mathrm{mg} \cdot \mathrm{g}^{-1}$ in site 4 where they re-increase up to $300 \mathrm{mg} \cdot \mathrm{g}^{-1}$ at the bottom of the latter profile (Fig. 5). In the unexploited site, the amounts of sugars progressively decrease with increasing depth (from 327 to $200 \mathrm{mg} \cdot \mathrm{g}^{-1}$ ), except at $20-25 \mathrm{~cm}$ and $48-62 \mathrm{~cm}$ where they slightly decrease to 200 and $147 \mathrm{mg} \cdot \mathrm{g}^{-1}$ respectively.

In the whole profiles, total hemicellulose contents are higher than those of total cellulose sugars (Fig. 5). Moreover, it is worth noting that a greater discrepancy between their amounts occurs only in the upper sections of sites 1 and 4 (ca. 200 to $300 \mathrm{mg} . \mathrm{g}^{-1}$ for hemicelluloses versus ca. 50 to $100 \mathrm{mg} \cdot \mathrm{g}^{-1}$ for cellulose, respectively). However, both in the deeper peat and all along the unexploited site profile they show similar patterns (Fig. 5).

The relative percentages of individual hemicellulose sugars (wt $\%)$ also show different features when comparing the three profiles. At sites 1 and 4, mannose, and to a lesser extent, galactose and rhamnose, are present in a relatively high proportion in the surface peat $(<20 \mathrm{~cm} ; \%$ of mannose up to $40 \%$ at site 4$)$. In contrast, xylose and arabinose concentrations, which are relatively low in this peat section, significantly 
increase below (section 20-45 cm depth) (Fig. 5). At the unexploited site, relative hemicellulose sugar contents show almost constant values along the profile, except (i) at $20 \mathrm{~cm}$ depth where rhamnose and mannose slightly decreases and increases respectively and (ii) at ca. $32 \mathrm{~cm}$ depth where xylose significantly increases.

\section{DISCUSSION}

To our knowledge this is the first study to compare how microbial, biochemical and micromorphological indicators vary on a cutover peatland where the surface is in different stages of regeneration. Both biological and physico-chemical indicators are consistent in showing clear differences between the profiles from the unexploited part of the peatland and those from its regenerating parts.

\section{Testate amoebae and bacteria indicators:}

Testate amoebae can be identified to the species level and can be related to regional ecological calibration data sets developed for paleoecological studies (Charman \& Warner 1992; Charman 1997; Booth 2001, Charman 2001; Booth 2002; Lamentowicz \& Mitchell 2005; Payne et al. 2006). This constitutes a clear advantage for testate amoebae as management tools for peatland resources (Mitchell, Charman \& Warner In press). The quantitative inference of water table depth and $\mathrm{pH}$ based on testate amoebae indicators represents an alternative to labour-intensive repeated measurements of these variables in the field (Charman et al. 2004).

Nevertheless, to date testate amoebae have only rarely been included in studies of cutover peatland regeneration (Buttler et al. 1996; Davis \& Wilkinson 2004). In a study of naturally regenerating cutover bogs in the Jura Mountains, Buttler et al. (1996) observed that testate amoebae responded fast to changes occurring at the 
surface. They observed a convergence of vegetation and testate amoeba community structure in the late regeneration stage, regardless of the initial conditions.

Beyond quantitative estimates in water table depth and $\mathrm{pH}$, we observed clear differences in species richness, diversity, density, biomass and average species size. Species richness and diversity increased but density declined from the early to the late regeneration stage and the unexploited site. The increasing species richness and diversity from the early to the more advanced stage are in agreement with the patterns of community assembly of various groups of organisms during primary or secondary succession (Odum 1971). However, recent studies of testate amoeba diversity and community structure in chronosequences and relationships between plant and testate amoeba diversity showed contrasting responses sugesting that testate amoebae my not respond like larger organisms ( Ledeganck, Nijs \& Beyens 2003; Wanner \& Xylander 2005). In the cutover peatland secondary succession sequence we found shifts in community composition and not simply an addition of new taxa as observed by Wanner \& Xylander (2005) in sand dunes. However, peatlands are different from sand dunes or mineral soils in their evolution. It can be assumed that the changes in ecological conditions (e.g. moisture and $\mathrm{pH}$ ) associated with the development of a new, actively growing peat layer acts as a strong ecological filter that prevent early colonisers from maintaining themselves in the community.

Biomass and the average size of species declined over the regeneration sequence but were higher in the unexploited site of La Chaux d'Abel peatland. These changes also agree well with the changes in ecological conditions over the regeneration sequence. Testate amoebae are aquatic organisms and respond to soil moisture content in a size (or biovolume)-specific way: large species are more stimulated by wet conditions than small species (Lousier 1974). Genera such as 
Arcella, Bullinularia, Centropyxis, Trinema and Corythion have adapted to dry conditions by evolving a ventral aperture and a flattened shell that allows them to creep within a thin capillary film and thus reach a larger size than if they had a terminal aperture (Bonnet 1964). If true, why then did we observe on average larger testate amoebae in the unexploited site compared to advanced regeneration sites?

We interpret the difference between the community structure of the advanced regeneration and unexploited sites as an indication of the different recolonisation potential of different testate amoeba taxa. Species such as Bullinularia indica, which are among the largest testate amoebae found in Sphagnum-dominated peatlands (and the largest in our data set), never reach high numbers, most likely because of a (relatively) slow rate of reproduction, although there is only limited data on the relationship between size and reproduction rates of testate amoebae (Schönborn 1986 and references therein). Therefore we would not expect large species to colonise favourable habitats very fast. By contrast smaller species such as Assulina muscorum or Euglypha species, which are usually more abundant, have a higher colonisation potential. It follows that in the more advanced regeneration stages we should expect to find more relatively small species, albeit a community indicative for dry and acidic conditions similar to that of unexploited but drained sites. Such differences in the size and quality of the testate population may serve as predictors of the rate and directions of change as the regenerating peat community becomes better established. Beyond the quantitative inference of key ecological variables, the structure of the testate amoeba community might provide information on the degree of "naturalness" of a site.

Bacterial biomass is a relatively crude measure of microbial activity in ecosystems including secondary succession in cutover peatlands. Nevertheless clear changes were observed. Beyond biomass, changes in bacterial community structure 
and associated processes can be expected. A community approach for bacteria was beyond our goals for the bacteria, but testate amoebae provide more information as these were identified to the species level. Low densities of bacteria were recorded during the apparently drier phases (see the following section), and in the more advanced regeneration stages (albeit not significant). Similarly, Gilbert (1998) observed lower chemo-heterotrophic assimilation (mainly bacterial) during the dry period of mid-summer in a Sphagnum-dominated peatland. This apparent negative effect of dry conditions on bacteria density and production parallels the pattern of testate amoeba density where low numbers were found in the more advanced, drier secondary sites and in the unexploited site. Testate amoebae feed on a broad range of micro-organisms (Yeates \& Foissner 1995; Gilbert et al. 2000). Thus the lower density of testate amoebae in the drier sites is in agreement with the density patterns of at least some of their prey (the bacteria) and micobial secondary production. These results could also suggest that the larger species of testate amoebae that are characteristic for the unexploited site may be less directly dependant on the abundance of bacteria and instead feed more (or perhaps exclusively) on fungi. Such an assumption is commonly made although there is still little reliable data on the feeding habits of most testate amoeba species.

\section{Organic matter and physico-chemical indicators:}

The high preservation of organic material in peat that results from low $\mathrm{pH}$ and anoxia make the peat archives particularly useful for palaeoenvironmental reconstructions. Nevertheless, to this date the biochemical composition of peat OM has rarely been used as indicator for past environmental conditions, particularly in ombrotrophic peatlands (e.g. Morita \& Montgomery 1980; Nott et al. 2000; Pancost et al. 2002; Nichols et al. 2006), and none of these studies concern formerly cutover sites. 
Recently, a study of a regenerating cutover bog in the Jura Mountains allowed Comont, Laggoun-Défarge \& Disnar (2006) to obtain insights into changes in the OM sources and the dynamics of inherited biopolymers along the regeneration sequence.

The irregular but overall progressive decrease of total sugars with increasing depth evidenced in the unexploited site depicts typical diagenetic evolution (Fig. 5). Nevertheless, the high and nearly constant $\mathrm{C} / \mathrm{N}$ ratio values (i.e. 60 to 80 ) recorded along the peat profile, are typical of rather well preserved inherited plant material. This latter statement is supported by microscopic counts that revealed an abundance of well-preserved tissues mainly derived from Sphagnum mosses (Fig. 3). In contrast, the two sections taken between $20-25$ and $48-62 \mathrm{~cm}$ depth that display much lower $\mathrm{C} / \mathrm{N}$ ratios, lower total sugar yields, and OM dominated by decomposed plant tissues suggest an increasing degradation of OM. At the top of these two sections wellpreserved Cyperaceae-derived tissues replaced the Sphagnum-derived tissues. These features suggest a change in vegetation and environmental conditions that might have been provoked by drier phases in the history of the bog. Such a dry even would have shifted the competition between Sphagnum and Eriophorum in favour of the latter and increased peat mineralisation. The causes of these dry phases are uncertain but could be related either to climatic fluctuations (Mauquoy \& Barber 1999; Barber, Chambers \& Maddy 2003; Booth \& Jackson 2003; McMullen, Barber \& Johnson 2004) or to two successive phases of peat exploitation between which the vegetation was able to recover. Taken together, these results illustrate well the fact that although this part of the bog has not been exploited for peat, either climate change or drainage related to peat harvesting affected both the vegetation (and therefore the botanical composition of the peat) and the evolution of the existing peat. 
In the regenerating sites, vertical patterns of OM composition revealed a limit between the upper "new" peat and the lower "old" catotelm peat. The latter one, especially in site 1 profile, was characterised by a pronounced OM degradation as attested by relative low $\mathrm{C} / \mathrm{N}$ ratios and sugar contents and a predominance of amorphous $\mathrm{OM}$ and mucilage. In contrast, the "new" regenerated peat showed contrasting features in terms of plant sources and degradation/preservation of the OM. Microscopic counts revealed that the "new" peat was dominated by moss-derived tissues. This assessment was confirmed by distributions of individual hemicellulose sugars displaying high proportions of mannose and, in a lesser extent galactose, compounds typical for mosses (Comont, Laggoun-Défarge \& Disnar 2006). In addition, the "new" peat exhibited much higher yields of total hemicellulosics in comparison to total cellulosic sugars. Such a discrepancy might reflect a higher contribution of moss to the peat, these plants being richer in hemicellulosic sugars than sedges (Comont, Laggoun-Défarge \& Disnar 2006). However, here a relative enrichment of the hemicellulosic carbohydrate pool as a result of cellulose destructuration cannot be excluded (Comont, Laggoun-Défarge \& Disnar 2006). Nevertheless, the amounts of total sugars recorded in this peat layer, which are in the same range as in living plants, are indicative for a good OM preservation. This later statement is also fully supported by high $\mathrm{C} / \mathrm{N}$ ratios as well as by well-preserved and recognisable Sphagnum and Polytrichum-derived tissues in the regenerated peat layer both at sites 1 and 4 . Surprisingly, although the vegetation cover is nowadays dominated by mosses and sedges, no evidence of any Cyperaceae-derived material and/or related biomarkers has been identified either by microscopic counts or sugar analyses. In fact, xylose and arabinose, which are characteristic of Cyperaceae (Bourdon et al. 2000), are present at higher levels in the "old" peat than in the "new" 
one (Fig. 5). The overall lack of Eriophorum record in the "new" peat, particularly in site 1, can at first be attributed to its higher decomposability compared to Sphagnum mosses (Coulson \& Butterfield 1978; Clymo \& Hayward 1982; Chague-Goff \& Fyfe 1996).

A close examination of organic composition of the "new" peat at the two regenerating sites actually revealed contrasting signatures. In site 1 the peat was strongly dominated by Sphagnum-remains, while in site 4, it was much more heterogeneous with Polytrichum remains, amorphous OM and Cyperaceae-derived tissues at the bottom of the section. Furthermore, a better carbohydrate preservation was depicted in the latter peat (ca. $337 \mathrm{mg} \cdot \mathrm{g}^{-1}$ versus ca. $243 \mathrm{mg} \cdot \mathrm{g}^{-1}$ at site 1 ). In addition to the original botanical composition, such a contrasting composition might also be related to abiotic factors, i.e. trophic conditions inducing differences in biodegradation processes between site 1 and site 4 . In fact, the surface vegetation suggests that the environmental conditions of the recent regenerating stage (site 1) are probably more minerotrophic, and consequently more favourable to microbial activity than the more advanced regenerating stage (site 4) (Unpublished data, Samaritani et al.). This explanation was supported by the bacterial biomass which was about twice as high in the "new" peat of the recent regenerating stage as in the advanced stage and the unexploited site. Results on testate amoebae also confirmed these features: the higher densities and $\mathrm{C}$ biomass being associated to the recent regeneration stage and the community patterns clearly showing a shift from a fen community towards a more acidic, drier bog community. In the same way, when considering the whole profiles (new and old peat), it appeared that the highest bacterial biomass was recorded in the Sphagnum-dominated peat layers and the lowest one in the highly decomposed and 
deeper peat layers that were interpreted, at least at site 1 , as consequence of drainage phases during the peat extraction.

\section{CONCLUSIONS}

Our aims were to assess how testate amoebae, bacteria, and peat OM correlated and to identify specific indicators of changes in the structure or the functioning of the ecosystem. From this comparative study the following emerged:

While bulk chemical OM characterisation revealed by $\mathrm{C} / \mathrm{N}$ profiles, allowed the newly regenerated peat to be differentiated from old peat, $\mathrm{OM}$ indicators (carbohydrates and botanical composition of the peat) combined with heterotrophic bacteria biomass and testate amoebae diversity revealed contrasting signatures between the recent and the advanced stages of regeneration.

Differences observed in the composition of the newly accumulated peat may be due not only to plant sources but also to trophic and abiotic conditions inducing differences in biodegradation processes between the two stages. This interpretation was supported by testate amoebae communities and bacterial biomass.

In the natural unexploited site, specific OM indicators provided information on past changes in vegetation and related environmental conditions, well recorded in the accumulated peat.

Understanding ecosystem dynamics in secondary ecosystems is challenging because we rarely have accurate information on the nature of the ecosystem prior to disturbance and a detailed account of human impact. It is therefore valuable to compare independent lines of evidence to determine such characteristics of the site. A 
multidisciplinary assessment approach may therefore prove useful for the management of abandoned cutover peatlands.

\section{Acknowledgements}

This paper is a contribution of the RECIPE project (reconciling commercial exploitation of peat with biodiversity in peatland ecosystems) which is partly supported by the European Commission ( ${ }^{\circ}$ EVK2-CT-2002-00154) and partly by the OFES (Swiss federal office for education and science). The authors gratefully acknowledge analytical assistance provided by A. Fleury, M. Hatton and N. Lottier and critical comments from Steve Chapman. 
References

Barber, K.E., Chambers, F.M. \& Maddy, D. (2003) Holocene palaeoclimates from peat stratigraphy: macrofossil proxy climate records from three oceanic raised bogs in England and Ireland. Quaternary Science Reviews, 22, 521-39.

Bonnet, L. (1964) Le peuplement thécamobiens des sols. Revue d'Ecologie et de Biologie du Sol, 1(2), 123-408.

Booth, R.K. (2001) Ecology of testate amoebae (Protozoa) in two lake superior coastal wetlands: Implications for paleoecology and environmental monitoring. Wetlands, 21(4), 564-76.

Booth, R.K. (2002) Testate amoebae as paleoindicators of surface-moisture changes on Michigan peatlands: modern ecology and hydrological calibration. Journal of Paleolimnology, 28, 329-48.

Booth, R.K. \& Jackson, S.T. (2003) A high resolution record of late-Holocene moisture variability from a Michigan raised bog, USA. The Holocene, 13(6), 86376.

Bourdon, S., Laggoun-Défarge, F., Maman, O., Disnar, J.-R., Guillet, B., Derenne, S. \& Largeau, C. (2000) Organic matter sources and early diagenetic degradation in a tropical peaty marsh (Tritrivakely, Madagascar). Implications for environmental reconstruction during the Sub-Atlantic. Organic Geochemistry, 31, 421-38.

Bratbak, G. (1985) Bacterial biovolume and biomass estimations. Applied and Environmental Microbiology, 46, 491-98.

Buttler, A., Dinel, H. \& Lévesque, P.M.E. (1994) Effects of physical, chemical and botanical characteristics of peat on carbon gas fluxes. Soil Science, 158, 365-74.

Buttler, A., Grosvernier, P. \& Matthey, Y. (1998) Development of Sphagnum fallax diaspores on bare peat with implications for the restoration of cut-over bogs. Journal of Applied Ecology, 35(5), 800-10.

Buttler, A., Warner, B.G., Grosvernier, P. \& Matthey, Y. (1996) Vertical patterns of testate amoebae (Protozoa: Rhizopoda) and peat forming vegetation on cutover bogs in the Jura, Switzerland. New Phytologist, 134, 371-82.

Chague-Goff, C. \& Fyfe, W.S. (1996) Geochemical and petrographical characteristics of a domed bog, Nova Scotia: a modern analogue for temperate coal deposits. Organic Geochemistry, 24, 141-58. 
Chapman, S., Buttler, A., Francez, A.-J., Laggoun-Défarge, F., Vasander, H., M., S., Combe, J., Grosvernier, P., Harms, H., Epron, D., Gilbert, D. \& Mitchell, E.A.D. (2003) Commercial exploitation of peatlands and maintenance of biodiversity - A conflict between economy and ecology. Frontiers in Ecology and the Environment, 1(10), 525-32.

Charman, D.J. (1997) Modelling hydrological relationships of testate amoebae (Protozoa : Rhizopoda) on New Zealand peatlands. Journal of the Royal Society of New Zealand, 27(4), 465-83.

Charman, D.J. (2001) Biostratigraphic and palaeoenvironmental applications of testate amoebae. Quaternary Science Reviews, 20(16-17), 1753-64.

Charman, D.J., Aravena, R. \& Warner, B. (1994) Carbon dynamics in a forested peatland in north-estern Ontario, Canada. Journal of Ecology, 82, 55-62.

Charman, D.J., Brown, A.D., Hendon, D. \& Karofeld, E. (2004) Testing the relationship between Holocene peatland palaeoclimate reconstructions and instrumental data at two European sites. Quaternary Science Reviews, 23, 13743.

Charman, D.J. \& Warner, B.G. (1992) Relationship between testate amebas (Protozoa, Rhizopoda) and microenvironmental parameters on a forested peatland in Northeastern Ontario. Canadian Journal of Zoology-Revue Canadienne De Zoologie, 70(12), 2474-82.

Clymo, R.S. \& Hayward, P.M. (1982). The ecology of Sphagnum. In Bryophyte ecology (ed A.J.E. Smith), pp. 229-89. Chapman and Hall, London and New York.

Comont, L., Laggoun-Défarge, F. \& Disnar, J.-R. (2006) Evolution of organic matter indicators in response to major environmental changes: the case of a formerly cut-over peatbog (Le Russey, Jura Mountains, France). Organic Geochemistry, $37,1736-51$.

Coulson, J.C. \& Butterfield, J. (1978) An investigation of the biotic factors determining the rates of plant decomposition on blanket bog. Journal of Ecology, 66, 631-50.

Davis, S.R. \& Wilkinson, D.M. (2004) The conservation management value of testate amoebae as 'restoration' indicators: speculations based on two damaged raised mires in northwest England. The Holocene, 14 (1), 135-43. 
Decho, A.W. (1990) Microbial exopolymer secretions in ocean environments: their role(s) in food webs and marine processes. Annual Review of Oceanography and Marine Biology, 28, 73-153.

Défarge, C., Trichet, J., Jaunet, A.-M., Robert, M., Tribble, J. \& Sansone, F.J. (1996) Texture of microbial sediments revealed by cryo-scanning electron microscopy. Journal of Sedimentary Research, 66, 935-47.

Francez, A.J., Gogo, S. \& Josselin, N. (2000) Distribution of potential $\mathrm{CO}_{2}$ and $\mathrm{CH}_{4}$ productions, denitrification and microbial biomass $\mathrm{C}$ and $\mathrm{N}$ in the profile of a restored peatland in Brittany (France). European Journal of Soil Biology, 36(3-4), $161-68$.

Gilbert, D. (1998) Les communautés microbiennes à la surface des tourbières à sphaignes: structure, fonctionnement et impact des apports de fertilisants. $\mathrm{PhD}$ thesis, University Blaise Pascal, Clermont-Ferrand, France.

Gilbert, D., Amblard, C., Bourdier, G. \& Francez, A.-J. (1998a) The microbial loop at the surface of a peatland: Structure, function, and impact of nutrient input. Microbial Ecology, 35(1), 83-93.

Gilbert, D., Amblard, C., Bourdier, G. \& Francez, A.J. (1998b) Short-term effect of nitrogen enrichment on the microbial communities of a peatland. Hydrobiologia, 374, 111-19.

Gilbert, D., Amblard, C., Bourdier, G., Francez, A.-J. \& Mitchell, E.A.D. (2000) Le régime alimentaire des thécamoebiens. L’Année Biologique, 39, 57-68.

Gorham, E. \& Rochefort, L. (2003) Peatland restoration: A brief assessment with special reference to Sphagnum bogs. Wetlands Ecology and Management, 11, $109-19$.

Grosvernier, P., Matthey, Y. \& Buttler, A. (1995). Microclimate and physical properties of peat: new clues to the understanding of bog restoration processes. In Restoration of temperate wetlands (eds B.D. Wheeler, S.C. Shaw, W.S. Fojt \& R.A. Robertson), pp. 437-50. John Wiley \& Sons, Chichester, UK.

Grosvernier, P., Matthey, Y. \& Buttler, A. (1997) Growth potential of three Sphagnum species in relation to water table level and peat properties with implications for their restoration in cut-over bogs. Journal of Applied Ecology, 34(2), 471-83.

Harriss, R.C., Gorham, E., Sebacher, D.I., Bartlett, K.B. \& Flebbe, P.A. (1985) Methane flux from northern peatlands. Nature, 315, 652-54. 
Hendon, D. \& Charman, D.J. (1997) The preparation of testate amoebae (Protozoa: Rhizopoda) samples from peat. The Holocene, 7(2), 199-205.

Knowles, T.R. \& Moore, R. (1989) The influence of water table levels on methane and carbon dioxide levels from peatland soils. Canadian Journal of Soil Science, 69(1), 33-38.

Laggoun-Défarge, F., Bourdon, S., Chenu, C., Défarge, C. \& Disnar, J.-R. (1999). Etude des transformations morphologiques précoces des tissus végétaux de tourbe. Apport du marquage histochimique en MET et du cryo-MEB haute résolution. In Structure et ultrastructure des sols et des organismes vivants (eds F. Elsass \& A.-M. Jaunet), pp. 169-82. INRA, Paris.

Lamentowicz, M. \& Mitchell, E.A.D. (2005) The ecology of testate amoebae (Protists) in Sphagnum in north-west Poland in relation to peatland ecology. Microbial Ecology, 50(1), 48-63.

Lavoie, C., Grosvernier, P., Girard, M. \& Marcoux, K. (2003) Spontaneous revegetation of mined peatlands: An useful restoration tool? Wetlands Ecology and Management, 11, 97-107.

Ledeganck, P., Nijs, I. \& Beyens, L. (2003) Plant functional group diversity promotes soil protist diversity. Protist, 154, 239-49.

Line, J.M., ter Braak, C.J.F. \& Birks, H.J.B. (1994) WACALIB version 3.3 - a computer program to reconstruct environmental variables from fossil assemblages by weighted averaging and to derive sample-specific errors of prediction. Journal of Paleolimnology, 10, 147-52.

Lousier, J.D. (1974) Response of soil testacea to soil moisture fluctuations. Soil Biology \& Biochemistry, 6(4), 235-39.

Matthey, Y. (1996) Conditions écologiques de la régénération spontannée du Sphagnion Magellanici dans le Jura Suisse. PhD Thesis, University of Neuchâtel, Switzerland.

Mauquoy, D. \& Barber, K. (1999) Evidence for climatic deteriorations associated with the decline of Sphagnum imbricatum Hornsch ex Russ. in six ombrotrophic mires from northern England and the Scottish Borders. The Holocene, 9(4), 42337.

McMullen, J.A., Barber, K.E. \& Johnson, B. (2004) A paleoecological perspective of vegetation succession on raised bog microforms. Ecological Monographs, 74(1), 45 . 
McNeil, P. \& Waddington, J.M. (2003) Moisture controls on Sphagnum growth and CO2 exchange on a cutover bog. Journal of Applied Ecology, 40(2), 354-67.

Meisterfeld, R. (2000a). Order Arcellinida Kent, 1880. In The illustrated guide to the protozoa (eds J.J. Lee, G.F. Leedale \& P. Bradbury), Vol. 2, pp. 827-60. Society of protozoologists, Lawrence, Kansas, USA.

Meisterfeld, R. (2000b). Testate amoebae with filopodia. In The illustrated guide to the protozoa (eds J.J. Lee, G.F. Leedale \& P. Bradbury), Vol. 2, pp. 1054-84. Society of protozoologists, Lawrence, Kansas, USA.

Mitchell, E.A.D., Buttler, A.J., Warner, B.G. \& Gobat, J.M. (1999) Ecology of testate amoebae (Protozoa : Rhizopoda) in Sphagnum peatlands in the Jura mountains, Switzerland and France. Ecoscience, 6(4), 565-76.

Mitchell, E.A.D., Charman, D.J. \& Warner, B.G. (In press) Testate amoebae analysis in ecological and paleoecological studies of wetlands: past, present and future. Biodiversity and Conservation, In press.

Mitchell, E.A.D., Gilbert, D., Buttler, A., Amblard, C., Grosvernier, P. \& Gobat, J.M. (2003) Structure of microbial communities in Sphagnum peatlands and effect of atmospheric carbon dioxide enrichment. Microbial Ecology, 46(2), 187-99.

Mitchell, E.A.D., van der Knaap, W.O., van Leeuwen, J.F.N., Buttler, A., Warner, B.G. \& Gobat, J.M. (2001) The palaeoecological history of the Praz-Rodet bog (Swiss Jura) based on pollen, plant macrofossils and testate amoebae (Protozoa). The Holocene, 11(1), 65-80.

Moore, T.R. \& Knowles, R. (1989) The influence of water table levels on methane and carbon dioxide emissions from peatland soils. Canadian Journal of Soil Science, 69, 33-38.

Morita, H. \& Montgomery, W.G. (1980) Monosaccharide composition of selected Canadian peats Canadian Journal of Soil Science, 60, 1-7.

Nichols, J.E., Booth, R.K., Jackson, S.T., Pendall, E.G. \& Huang, Y. (2006) Paleohydrologic recpnstruction based on n-alkane distributions in ombrotrophic peat. Organic Geochemistry, 37, 1505-13.

Noël, H. (2001) Caractérisation et calibration des flux organiques sédimentaires dérivant du bassin versant et de la production aquatique (Annecy, Le Petit Lac). Rôles respectifs de l'Homme et du Climat sur l'évolution des flux organiques au cours des 6000 dernières années, $\mathrm{PhD}$ thesis, University of Orléans, France. 
Nott, C.J., Xie, S.C., Avsejs, L.A., Maddy, D., Chambers, F.M. \& Evershed, R.P. (2000) n-Alkane distributions in ombrotrophic mires as indicators of vegetation change related to climatic variation. Organic Geochemistry, 31(2-3), 231-35.

Odum, E.P. (1971) Fundamentals of Ecology, Third Edition edn. W. B. Saunders Co., Philadelphia - London - Toronto.

Pancost, R.D., Baas, M., Van Geel, B. \& Sinninghe Damsté, J.S. (2002) Biomarkers as proxies for plant inputs to peats: an example from a sub-boreal ombrotrophic bog. Organic Geochemistry, 33, 675-90.

Payne, R.J., Kishaba, K., Blackford, J.J. \& Mitchell, E.A.D. (2006) Ecology of testate amoebae (Protista) in south-central Alaska peatlands: building transfer-function models for palaeoenvironmental studies. The Holocene, 16(3), 403-14.

Schönborn, W. (1986) Population dynamics and production biology of testate amoebae (Rhizopoda, Testacea) in raw humus of two coniferous forest soils. Archiv Fur Protistenkunde, 132, 325-42.

Wanner, M. \& Xylander, W.E.R. (2005) Biodiversity development of terrestrial testate amoebae: is there any succession at all? Biology and Fertility of Soils, $\mathbf{4 1}$, 428-38.

Warner, B.G. \& Chmielewski, J.G. (1992) Testate amoebae (Protozoa) as indicators of drainage in a forested mire, northern Ontario, Canada. Archiv Fur Protistenkunde, 141(3), 179-83.

Weisse, T., Muller, H., Pinto-Coelho, R.M., Schweizer, A., Springmann, D. \& Baldringer, G. (1990) Response of the microbial loop to the phytoplankton spring bloom in a large prealpine lake. Limnology and Oceanography, 35, 781-94.

Yeates, G.W. \& Foissner, W. (1995) Testate Amebas as Predators of Nematodes.

Biology and Fertility of Soils, 20(1), 1-7. 


\begin{tabular}{|c|c|c|}
\hline Site & General description & Vegetation (dominant plants) \\
\hline Site 1 & $\begin{array}{l}\text { Regenerating zone in a part of the mire where } \\
\text { no intact portion remains. Fen vegetation }\end{array}$ & $\begin{array}{l}\text { Polytrichum strictum, P. commune, Sphagnum } \\
\text { fallax, Carex nigra, etc. }\end{array}$ \\
\hline Site 2 & $\begin{array}{l}\text { Same zone as stage } 1 \text {, but different dominant } \\
\text { plants species }\end{array}$ & Eriophorum vaginatum, Sphagnum fallax, etc. \\
\hline Site 3 & $\begin{array}{l}\text { Regenerating zone at the base of a peat } \\
\text { extraction wall, open mixed forest of birch and } \\
\text { pine }\end{array}$ & $\begin{array}{l}\text { Eriophorum vaginatum, Sphagnum fallax, } \\
\text { Betula pubescens, Pinus rotundata, etc. }\end{array}$ \\
\hline Site 4 & $\begin{array}{l}\text { Same zone, but drier and with different } \\
\text { dominant plant species }\end{array}$ & $\begin{array}{l}\text { Polytrichum strictum, P. commune, Sphagnum } \\
\text { fallax, Betula sp., Pinus rotundata, etc. }\end{array}$ \\
\hline Unexploited & $\begin{array}{l}\text { Intact raised bog, but under the influence of } \\
\text { lateral drainage from the peat cutting wall. Tall } \\
\text { pine forest with dense shrub cover. }\end{array}$ & $\begin{array}{l}\text { Pinus rotundata, Picea abies, Vaccinium } \\
\text { uliginosum. Moss layer dominated by non- } \\
\text { Sphagnum mosses, with discontinuous } \\
\text { Sphagnum patches. }\end{array}$ \\
\hline
\end{tabular}

Table 1. Characteristics of the sampling sites in La Chaux d'Abel peatland, Swiss Jura Mountains. 


\begin{tabular}{|c|c|c|c|c|c|c|c|c|c|}
\hline \multirow[b]{2}{*}{ Taxon } & \multirow[b]{2}{*}{$\mathrm{n}$} & \multicolumn{4}{|c|}{ Overall density [ind. / g d.w.] } & \multicolumn{4}{|c|}{ Overall relative frequency [\%] } \\
\hline & & Mean & SE & Min & Max & Mean & SE & Min & Max \\
\hline Archerella flavum * & 4 & 1438 & 691 & 0 & 7704 & 2,35 & 1,19 & 0,00 & 26,16 \\
\hline Arcella catinus & 7 & 357 & 141 & 0 & 1531 & 1,00 & 0,46 & 0,00 & 10,00 \\
\hline Assulina muscorum & 15 & 3146 & 954 & 274 & 15406 & 18,71 & 4,59 & 0,26 & 73,48 \\
\hline Assulina seminulum & 8 & 459 & 231 & 0 & 2914 & 1,62 & 1,02 & 0,00 & 23,03 \\
\hline Bullinularia indica & 5 & 136 & 79 & 0 & 1166 & 0,71 & 0,42 & 0,00 & 9,21 \\
\hline Centropyxis aculeata & 3 & 119 & 109 & 0 & 1636 & 0,25 & 0,10 & 0,00 & 1,89 \\
\hline Centropyxis aerophila var sphagnicola & 1 & 9 & 9 & 0 & 136 & 0,01 & 0,01 & 0,00 & 0,16 \\
\hline Corythion dubium & 11 & 978 & 518 & 0 & 8044 & 4,40 & 1,10 & 0,00 & 24,31 \\
\hline Euglypha ciliata-type & 11 & 746 & 206 & 0 & 2693 & 4,83 & 1,29 & 0,00 & 19,79 \\
\hline Euglypha compressa & 5 & 150 & 78 & 0 & 919 & 0,51 & 0,21 & 0,00 & 3,81 \\
\hline Euglypha laevis ** & 3 & 45 & 25 & 0 & 273 & 0,06 & 0,02 & 0,00 & 0,37 \\
\hline Heleopera sylvatica & 7 & 311 & 138 & 0 & 1996 & 1,23 & 0,46 & 0,00 & 9,52 \\
\hline Heleopera rosea & 10 & 318 & 138 & 0 & 2045 & 0,63 & 0,14 & 0,00 & 2,36 \\
\hline Hyalosphenia elegans & 3 & 219 & 129 & 0 & 1572 & 0,27 & 0,12 & 0,00 & 1,87 \\
\hline Hyalosphenia papilio & 13 & 30556 & 8542 & 0 & 91693 & 33,82 & 7,20 & 0,00 & 91,43 \\
\hline Hyalosphenia subflava & 1 & 7 & 7 & 0 & 98 & 0,02 & 0,01 & 0,00 & 0,33 \\
\hline Nebela militaris & 12 & 1087 & 651 & 0 & 10089 & 2,10 & 0,55 & 0,00 & 11,65 \\
\hline Nebela penardiana & 1 & 41 & 41 & 0 & 615 & 0,04 & 0,03 & 0,00 & 0,65 \\
\hline Nebela tincta & 14 & 4888 & 1139 & 0 & 12815 & 20,85 & 4,58 & 0,00 & 86,13 \\
\hline Nebela tincta var major & 14 & 3067 & 959 & 0 & 10756 & 4,69 & 1,04 & 0,00 & 19,52 \\
\hline Phryganella acropodia & 9 & 446 & 218 & 0 & 3136 & 1,32 & 0,43 & 0,00 & 8,94 \\
\hline Trigonopyxis arcula & 5 & 64 & 29 & 0 & 333 & 0,59 & 0,20 & 0,00 & 3,13 \\
\hline
\end{tabular}

* Synonym: Amphitrema flavum

** includes E. rotunda

Table 2. List of testate amoebae taxa identified in the Sphagnum samples from La Chaux d'Abel peatland. 


\begin{tabular}{|c|c|c|c|c|c|c|c|c|c|c|c|c|c|c|c|c|c|}
\hline & \multicolumn{3}{|c|}{ Site 1} & \multicolumn{2}{|c|}{ Site 2} & \multicolumn{3}{|c|}{ Site 3} & \multicolumn{3}{|c|}{ Site 4} & \multicolumn{2}{|c|}{ Unexploited } & \multicolumn{4}{|c|}{ All sites } \\
\hline & Ave. & SE $\neq$ & & Ave. & SE & Ave. & SE & & Ave. & SE & & Ave. & SE & Ave. & SE & Min & Max \\
\hline Species richness & 8,3 & 1,3 & $a b$ & 7,3 & $\mathrm{a}$ ad & 15 & 1,4 & $\mathrm{~b}$ & 10 & 1,2 & $a b$ & 14 & $0,9 a b$ & 10,8 & 0,9 & 4 & 17 \\
\hline H' Diversity index & 1,1 & 0,3 & a & 0,9 & 0,3 a & 2,7 & 0,3 & $b$ & 2,1 & 0,2 & $a b$ & 2,6 & $0,3 \mathrm{~b}$ & 1,89 & 0,22 & 0,53 & 3,23 \\
\hline$\%$ living and encysted & 63 & 2,9 & a & 64 & 6 & 49 & 10 & a & 50 & 2,3 & a & 52 & $1,2 \quad a$ & 55,6 & 2,7 & 32,3 & 75,6 \\
\hline Density $\left[10^{3}\right.$ ind./g d.w.] & 83 & 7 & a & 84 & 12 & 53 & 17 & $a b$ & 7,9 & 4,5 & $\mathrm{~b}$ & 16 & $2,4 \quad b$ & 48,6 & 9,4 & 3,3 & 104 \\
\hline$C$ biomass [ $\mu \mathrm{g}$ g.d.w. -1$]$ & 831 & 123 & & 1006 & 189 & 297 & 42 & c & 83 & 51 & c & 478 & $25 \mathrm{bc}$ & 539 & 99 & 21 & 1371 \\
\hline
\end{tabular}

* Lowercase letters indicate significant differences among sites in the ANOVA and Turkey-Kramer HSD comparison among pairs of sites. ‡ Standard errors $n=3$

Table 3. Summary data for testate amoebae extracted from Sphagnum samples taken in the five plant communities in La Chaux d'Abel peatland, Switerland 


\begin{tabular}{lrrrr}
\hline & S. fallax & P. strictum & E. vaginatum & E. angustifolium \\
\hline Total sugars (mg/g) & 357 & 401 & 326 & 282 \\
Total Cellulosics (mg/g) & 142 & 112 & 224 & 218 \\
Total Hemicellulosics (mg/g) & 215 & 289 & 102 & 64,5 \\
Hemicellulosic Glucose (w\%) & 27,3 & 30,6 & 13,5 & 15,2 \\
Xylose (w\%) & 16,2 & 4,51 & 52,4 & 47,9 \\
Arabinose (w\%) & 4,13 & 2,57 & 16,1 & 11,9 \\
Mannose (w\%) & 11,1 & 41,5 & 4,45 & 6,67 \\
Rhamnose (w\%) & 12,7 & 5,12 & 3,20 & 4,95 \\
Ribose (w\%) & 0,40 & 0,95 & 0,63 & 0,04 \\
Fucose (w\%) & 1,39 & 0,94 & 0,71 & 1,42 \\
Galactose (w\%) & 27,6 & 13,8 & 8,92 & 11,9 \\
\hline
\end{tabular}

Table 4. Yields of total sugars, cellulosics and hemicellulosics (mg. $\left.\mathrm{g}^{-1}\right)$ and distributions of hemicellulosic sugars (wt \%) for Sphagnum fallax, Polytrichum strictum, Eriophorum vaginatum and E. angustifolium collected in Le Russey, a peatland near La Chaux d'Abel in the Jura region of France (after Comont, LaggounDéfarge \& Disnar 2006). 


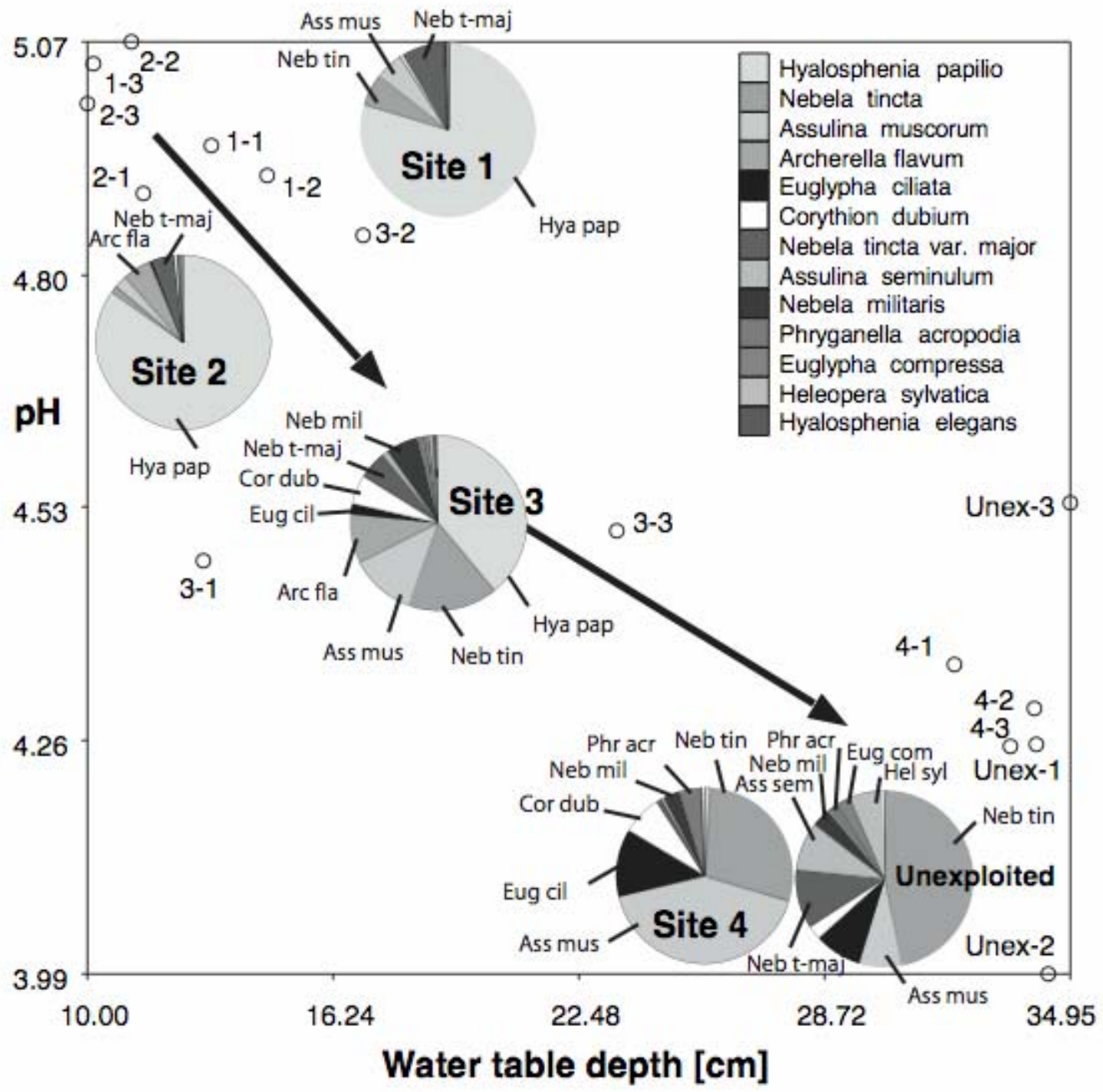

Fig. 1. Changes in testate amoeba community structure and inferred water table depth and $\mathrm{pH}$ in the regenerating vegetation and non-harvested bog. The water table and $\mathrm{pH}$ are inferred using a transfer-function from the Jura Mountains (Mitchell et al. 1999; Mitchell et al. 2001). 


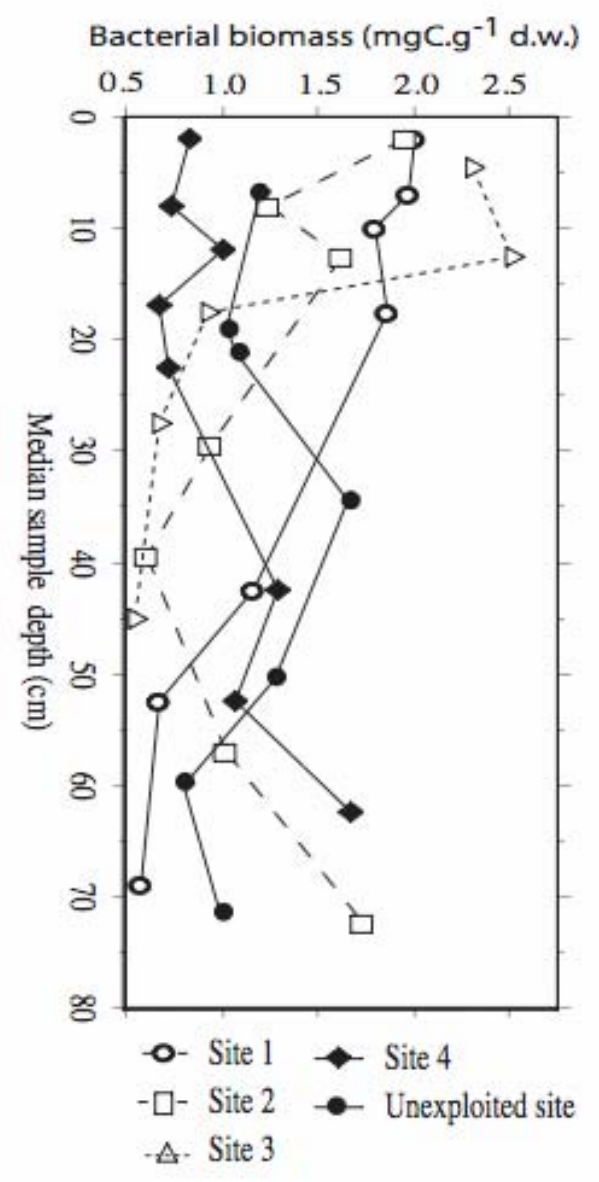

Fig. 2. Depth evolution of bacteria biomass in the early and advanced regenerating stages (sites 1,2,3,4) and the unexploited site. 


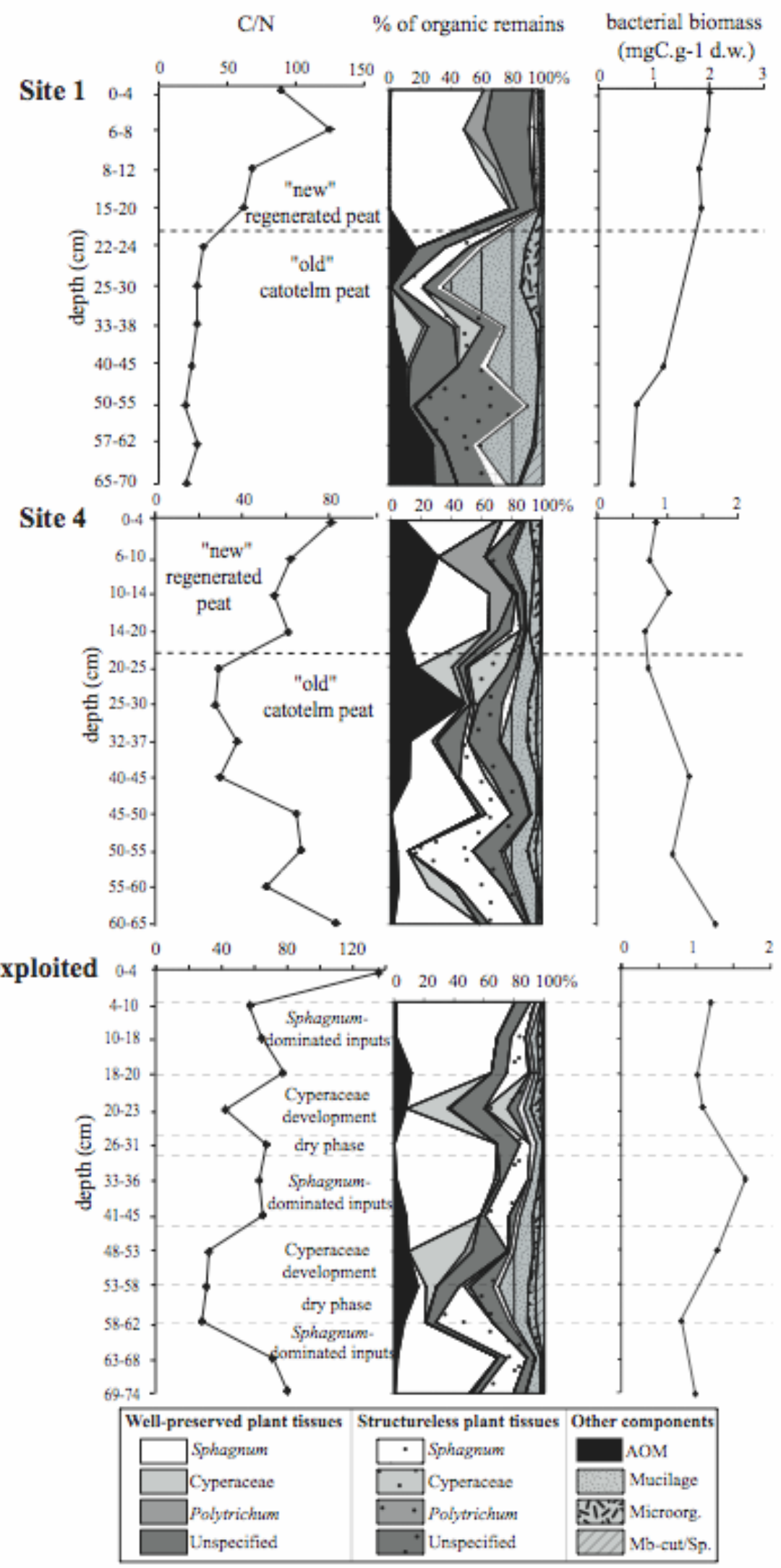


Fig. 3. Depth profiles of atomic $\mathrm{C} / \mathrm{N}$ ratio (i), relative percentages of organic microremains (ii), and bacterial biomass (iii) in the early regeneration stage (site 1), the advanced regeneration stage (site 4), and the unexploited site of La Chaux d'Abel peatland. The dotted line delineates the threshold between the uppermost "new" regenerating peat and the "old" catotelm peat.

(AOM: Amorphous organic matter; Mb, Cut, Sp: membranes, cuticles, spores; GD, OD: gelified debris, oxidised debris). 

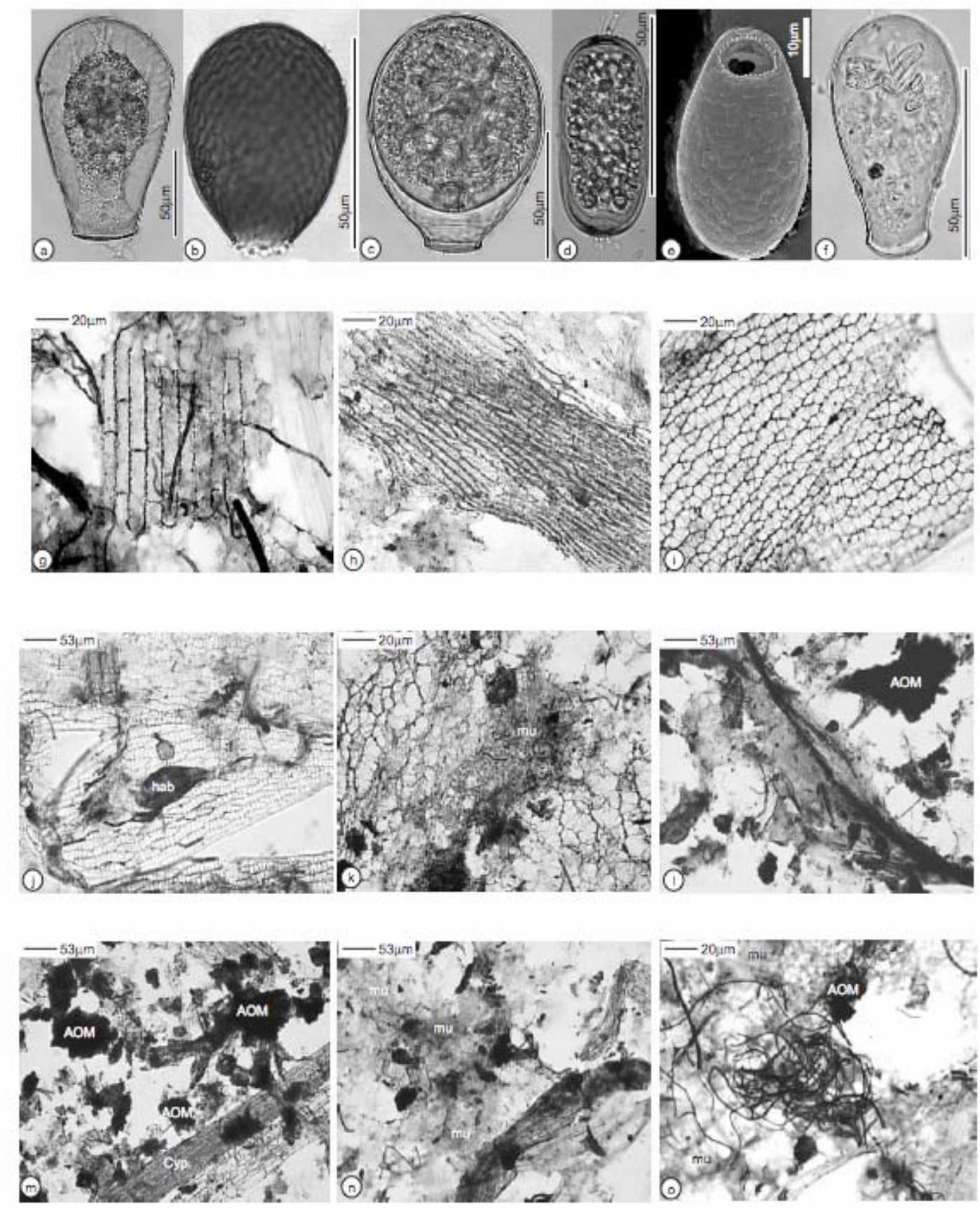

Fig. 4. Characteristic taxa of testate amoebae and main organic components identified in Sphagnum mosses and bulk peat samples, respectively: (a) Hyalosphenia papilio, (b) Assulina muscorum, (c) Nebela tincta, (d) Archerella flavum, (e) Corythion dubium, (f) Nebela militaris [scale bars $=50 \mu \mathrm{m}$ except for C. dubium $(10 \mu \mathrm{m})$ ], (g) Cyperaceae-derived leaf tissues, (h) Polytrichum-derived leaf tissues, (i) Sphagnumderived leaf tissues, (j) shell of the bdelloid rotifer Habrotrocha angusticollis (hab) associated with Sphagnum-derived leaf tissues, (k) degraded Sphagnum-derived leaf 
tissues and mucilage (mu), (l) structureless unspecified plant tissue and an amorphous OM (AOM) flake, (m) Amorphous OM (AOM) flakes and Cyperaceae-derived sheath tissue, (n) mucilage ( $\mathrm{mu}$ ) and structureless unspecified plant tissue (o) fungal hyphae, mucilage (mu) and an amorphous OM (AOM) flake. 
-Site 1-

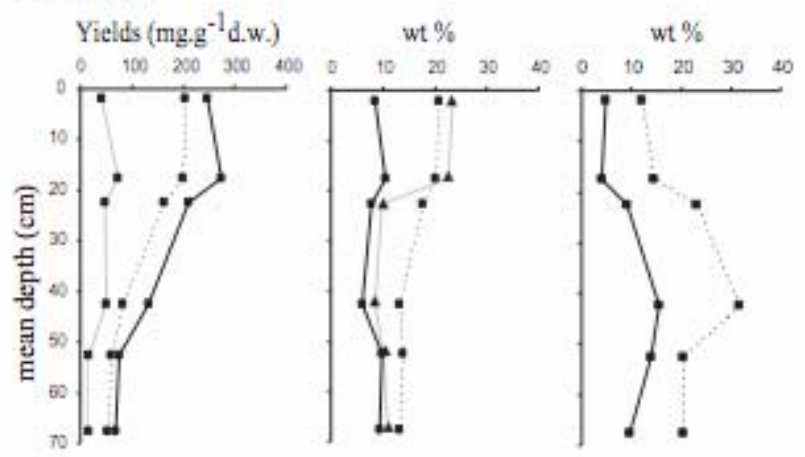

-Site 4-

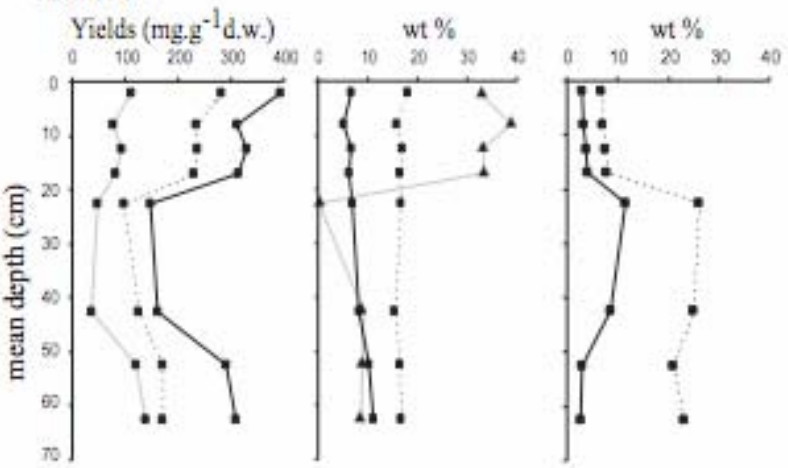

-Unexploited-

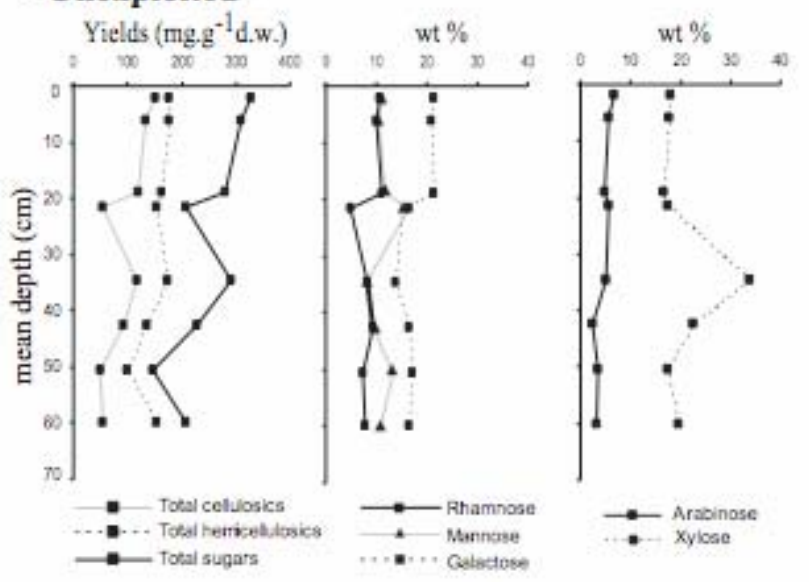

Fig. 5. Depth evolution of total sugar, cellulosics and hemicellulosics yields ( $\left.\mathrm{mg} \mathrm{g}^{-1}\right)$ and concentrations (wt\%) of moss and Cyperaceae markers in the early and advanced regenerating stages (sites 1 and 4) in comparison to the unexploited site. 